\title{
Refleksyjność w wychowaniu. Proces poznawania siebie
}

\begin{abstract}
ABSTRAKT
Refleksyiność jest cechq każdego człowieka, kompetenciq umysłowq zdolnościa człowieka do bycia dla siebie zarówno przedmiotem, jak również podmiotem poznania. Jest to rodzaj wewnętrznego dialogu, który przejawia się w konkretnych działaniach podejmowanych przez osobę. To skłonność do refleksji, zastanawiania się, rozważania, analizowania. Człowiek podejmując wysiłek myślenia nabywa zdolności do refleksyjności.
\end{abstract}

Wydaje się, że współczesna edukacja kładzie punkt ciężkości na kształcenie, pomijajqc aspekty wychowania i samowychowania. A przecież bezrefleksyjne, schematyczne wychowanie niesie z sobq wiele zagrożeń. W procesie wychowania, trwajacym przez całe życie człowieka, refleksyjność jest bardzo istotna i konieczna. W zwiqzku z tym przedmiotem badań podjętych w niniejszym tekście jest refleksyjność w kontekście procesu wychowania. Dlatego, w aspekcie teoretycznym, zostanie przedstawiona refleksyjność jako kategoria pedagogiczna. Następnie omówione zostanq podstawowe koncepcje refleksyjności przedstawione przez Johna Deweya, Jürgena Habermasa, Davida Kolba i Donalda Schöna. Ukazana będzie również refleksyjność w perspektywie procesu poznawania samego siebie.

Articles and dissertations
SLOWA KLUCZOWE

refleksja, refleksyjność, myślenie refleksyine, samopoznanie, proces wychowania

KEYWORDS

reflection, reflexivity, reflective thinking, self-knowledge, the process of upbringing

SPI Vol. 20, 2017/2

ISSN 2450-5358

e-ISSN 2450-5366

DOI: 10.12775/SPI.2017.2.006

Artykuły i rozprawy 
Tak ujmowana refleksyjność stanowi dla teorii pedagogicznej oraz edukacji istotny punkt odniesienia, bowiem dotyczy kluczowego problemu podmiotu i zachodzqcego $\mathrm{w}$ nim procesu stawania się.

\section{ABSTRACT}

Reflexivity is a characteristic of every human being, the mental competence and human ability to be both a subject and object of cognition. It is a kind of internal dialogue that manifests itself in the concrete actions undertaken by the person. It is prone to reflection, thinking about something, analysis. Man, when he makes the effort to think, acquires the ability to reflect.

It seems that modern education puts the focus on education aside from aspects of upbringing and self-education and yet an unreflective, schematic education brings with it many risks. In the process of upbringing, which lasts throughout human life, reflection is very important and necessary. Consequently, the subject of research of this paper is reflection in the context of the process of education. Therefore, in the theoretical aspect, reflections will be presented as a pedagogical category. Then we will discuss the basic concepts of reflexivity presented by John Dewey, Jürgen Habermas, David Kolb and Donald Schön. It will also show reflexivity from the perspective of the process of self-knowledge. Such reflectivity is a crucial point for pedagogical theory and education as it deals with the key problem of the subject and the process of becoming involved in it.

\section{Wprowadzenie}

Współczesnemu człowiekowi, zdaniem Andrzeja M. de Tchorzewskiego, „towarzyszy niespotykany dotąd pośpiech spowodowany dynamicznym rozwojem nowych technologii, które zmieniają jego dotychczasowe codzienne funkcjonowanie, jego orientację życiową, w której brakuje miejsca na refleksję dotyczącą sensu jego życia i bycia”"

$\mathrm{Z}$ analizy badań psychologicznych nad refleksyjnością prowadzonych przez Ellen Langer ${ }^{2}$ wynika, że bezrefleksyjność czy bezmyślność stają się coraz częstszym i powszechnym zjawiskiem. Problem

1 A.M. de Tchorzewski, Wstęp do teorii wychowania, Kraków 2016, s. 177.

2 Zob. E. Langer, Problemy uświadamiania. Konsekwencje refleksyjności i bezrefleksyjności, w: Poznanie. Afekt. Zachowanie, red. T. Maruszewski, Warszawa 1993. 
ten omawia również Wanda Woronowicz ${ }^{3}$, przestrzegając przed bezrefleksyjnym i automatycznym działaniem w różnych sytuacjach życiowych, kiedy to człowiek ulega naciskom innych osób i powszechnie przyjętym opiniom. Autorka słusznie zauważa, że „przed manipulacjami ze strony innych chroni nas nie tyle znajomość reguł i technik oddziaływania społecznego wpływu, które należałoby każdorazowo przywoływać i analizować, ile nawyk myślenia refleksyjnego"4 ${ }^{\mathrm{Na}}$ leży również zauważyć, że bezrefleksyjność prowadzi do złych decyzji i wyborów, a ,jej skutki mogą być katastrofalne" "Zapobiec temu może dokonanie namysłu nad własnym działaniem, analiza sytuacji i przemyślane postępowanie, czyli refleksyjność.

Zagadnienie refleksyjności w wymiarze takich kategorii, jak: refleksja, autorefleksja, refleksyjny nauczyciel, refleksyjna prakty$\mathrm{ka}$, prezentowane jest często $\mathrm{w}$ literaturze naukowej, szczególnie z pogranicza pedeutologii i dydaktyki. Wydaje się, że współczesna edukacja kładzie punkt ciężkości na kształcenie, pomijając aspekty wychowania i samowychowania. A przecież bezrefleksyjne, schematyczne wychowanie niesie $\mathrm{z}$ sobą wiele zagrożeń. W związku z tym przedmiotem badań podjętych w niniejszym tekście jest refleksyjność w kontekście procesu wychowania. Dlatego w aspekcie teoretycznym zostanie przedstawiona refleksyjność jako kategoria pedagogiczna, następnie omówione zostaną podstawowe koncepcje refleksyjności ze szczególnym uwzględnieniem wymiaru uczenia się oraz ukazana będzie refleksyjność jako proces poznawania siebie. Takie opracowanie zagadnienia refleksyjności stanowi wprowadzenie, podstawę do dalszych poszukiwań badawczych, których rozwiązania będzie można poszukiwać w badaniach empirycznych.

\section{Refleksyjność jako kategoria pedagogiczna}

We współczesnym dyskursie nauk humanistycznych i społecznych coraz większą rolę odgrywa pojęcie „refleksyjność”, które jest trudne do jednoznacznego określenia. Źródła z zakresu pedagogiki

3 Zob. W. Woronowicz, Dydaktyka wobec wptywu spotecznego, w: Edukacja jutra. VI Tatrzańskie Seminarium Naukowe, red. K. Denek, T.M. Zimny, Częstochowa 2000, s. 73-83.

4 W. Woronowicz, Dydaktyka wobec wptywu spotecznego, dz. cyt., s. 82.

5 Tamże, s. 76. 
i psychologii często stosują określenie refleksyjność w miejsce refleksji. W literaturze przedmiotu nie ma jednoznaczności w definiowaniu pojęć refleksja i refleksyjność. Należy zauważyć, że zarówno „refleksja”, jak i „refleksyjność” pochodzą od reflexio, -onis (zwrócić wstecz) jak i reflecto, -flexi (odbić, odzwierciedlić) czy refluo, -fluxi (płynąć wstecz) ${ }^{6}$. Tutaj ma również źródło wiele innych, pochodnych wyrażeń i znaczeń. Wydaje się zatem słuszne przedstawienie i odróżnienie tych dwóch pojęć.

Termin „refleksja” pochodzi od łacińskiego słowa reflexio, oznaczającego „zginanie, przechylanie, odbijanie, zawracanie”. W Encyklopedii pedagogicznej XXI wieku refleksja definiowana jest jako: „czynność umysłu polegająca na ujmowaniu lub tylko uświadamianiu własnych aktów (w tym samej refleksji) w aspekcie ich istnienia, zawartości, struktury i przebiegu”. Refleksja jest „podstawową cechą świadomości” "świadomym procesem myślowym przejawiającym się stwierdzeniu ,ja myślę", które nawiązuje do Kartezjuszowego cogito ergo sum (myślę, więc jestem) ${ }^{10}$.

Zdaniem Henryki Kwiatkowskiej, refleksja może być rozumiana jako „rodzaj myślenia, którego cechą jest ustawiczny namysł, rozważanie czegoś, dociekanie, ważenie problemu, jego różnych stron"11. Można zatem stwierdzić, że refleksja jest narzędziem do uświadamiania i odkrywania sensu myśli, poglądów i działania człowieka.

Człowiek podejmując wysiłek myślenia, nabywa zdolności do refleksyjności, która definiowana jest jako „skłonność do refleksji, do zastanawiania się, rozważania, analizowania"12. W pedagogicznym ujęciu, zdaniem Teresy Hejnickiej-Bezwińskiej, refleksyjność to „zdolność do analizowania uzyskiwanych doświadczeń oraz włą-

6 Por. E. Hałas, Refleksyjność jako zasada i problem teorii spotecznej, „Zagadnienia Naukoznawstwa" 2011, nr 2(188), s. 192-193.

7 W. Kopaliński, Stownik wyrazów obcych i zwrotów obcojezzycznych, Warszawa 1989, s. 433.

8 W. Chudy, Refleksja, w: Encyklopedia pedagogiczna XXI wieku, t. 5, red. T. Pilch, Warszawa 2006, s. 68.

9 Tamże, s. 68-69.

10 Por. tamże, s. 69.

11 H. Kwiatkowska, Pedeutologia, Warszawa 2008, s. 64.

12 Refleksyjnośc, w: Stownik języka polskiego, red. M. Szymczak, Warszawa 1981, s. 32. 
czania nowych danych, informacji, wiedzy do posiadanych struktur poznawczych i tworzenia nowych powiązań wiedzy z działaniem" ${ }^{\text {"13, }}$ zatem ważna staje się sama umiejętność dokonywania refleksji. Należy stwierdzić, że refleksyjność jest cechą każdego człowieka, kompetencją umysłową, zdolnością człowieka do bycia dla siebie zarówno przedmiotem, jak również podmiotem poznania. Można także uznać, że jest to rodzaj wewnętrznego dialogu, który przejawia się $\mathrm{w}$ działaniach podejmowanych przez osobę.

Podsumowując, warto zaznaczyć, że rozróżnienie między refleksją i refleksyjnością nie jest łatwe i oczywiste, ponieważ za tymi terminami kryje się wiele znaczeń, szczególnie wtedy, gdy stają się one kategoriami pojęciowymi teorii. W zależności od przyjętych założeń opracowane zostały różne koncepcje refleksyjności, na podstawie których można scharakteryzować refleksyjność.

\section{Koncepcje refleksyjności}

W literaturze przedmiotu, zarówno w aspekcie teoretycznym, jak również praktycznym, omawiane są różne teorie refleksyjności. Do klasycznych można zaliczyć między innymi koncepcje przedstawione przez Johna Deweya, Jürgena Habermasa, Davida Kolba i Donalda Schöna. Autorzy ci różnie ujmowali zagadnienie refleksyjności.

W koncepcji Johna Deweya refleksyjność opisana została jako specjalna forma myślenia, która polega na głębokim zastanawianiu się lub też analizowaniu własnego myślenia. „Myślenie refleksyjne jest czynnym, wytrwałym i uważnym rozważaniem jakiegoś mniemania lub przypuszczalnej formy wiedzy - w świetle podstaw, na których się wspiera, oraz wniosków, do których doprowadza" ${ }^{14}$. Istotne wydaje się zatem być mniemanie, czyli przypuszczalne rozwiązanie problemu, do którego doprowadzają rozważania refleksyjne. Podstawą zaś tego mniemania jest wiara (lub niewiara) „w pewną rzecz nie przez wzgląd na nią samą, ale dlatego, że inna rzecz o niej świadczy, jest jej dowodem i rękojmią" ${ }^{15}$. Na czynność refleksyjną składa jest „stan zakłopotania, zaniepokojenia, niepewności, wątpienia [...] akt badania lub

13 T. Hejnicka-Bezwińska, Pedagogika ogólna, Warszawa 2008, s. 502.

14 J. Dewey, Jak myślimy?, tłum. Z. Bastgenówna, Warszawa 1988, s. 29-30.

15 Tamże, s. 32. 
poszukiwania skierowanego ku wykryciu innych faktów, służących do potwierdzenia lub obalenia nasuwającego się mniemania"16. Należy zatem stwierdzić, że pojawiająca się wątpliwość jest początkiem aktu refleksji, z której wyłaniają się pomysły na wyjaśnienie problemu, następnie podlegają one selekcji w celu znalezienia właściwego rozwiązania. Konieczność „znalezienia rozwiązania wątpliwości jest czynnikiem nadającym stałość i kierunek całemu procesowi refleksji” ${ }^{17}$. Jest to jednocześnie „świadomy i dowolny wysiłek w celu oparcia mniemania na mocnych podstawach argumentów"18.

Należy zauważyć, że John Dewey ujmował refleksję holistycznie, jako obszar złożony z różnych efektów, które dotyczą funkcjonowania człowieka. Zdolność myślenia refleksyjnego wiąże się z umiejętnością celowego rozumienia własnych strategii myślenia, uczuć i działań. Jest to także osadzanie myśli i uczuć w przeżywanym doświadczeniu. Myślenie refleksyjne jest aktywnością umysłową, która rozwija się przez całe życie człowieka. Kształtuje się już od pierwszych lat życia, w okresie rozwoju inteligencji sensomotorycznej, następnie w okresie wczesnej adolescencji, nabiera charakteru operacyjno-formalnego, co przejawia się $\mathrm{w}$ dokonywaniu analizy i syntezy oraz wyciąganiu wniosków, a w pełni rozwija się w okresie dorosłości.

$Z$ kolei Jürgen Habermas ${ }^{19}$ przedstawił refleksyjność jako podstawę budowania teorii. W swojej koncepcji koncentrował się na tym, w jaki sposób ludzie przetwarzają różne informacje, jak tworzą nową wiedzę, budują pomysły i idee. W procesach tych refleksja jest ważna i konieczna. Autor omówił trzy rodzaje wiedzy: instrumentalną, interpretatywną oraz krytyczną. Wiedza instrumentalna odnosi się do zrozumienie otaczającej rzeczywistości po to, by móc ją kontrolować. Wiedza interpretatywna dotyczy rozumienia ludzkich działań i zachowań. Z kolei wiedza krytyczna odnosi się do procesów myślenia, bowiem prowadzi do przekształcenia myślenia, działania czy też sytuacji osobistej lub społecznej podmiotu. Refleksyjność najbardziej uwidacznia się w myśleniu krytycznym.

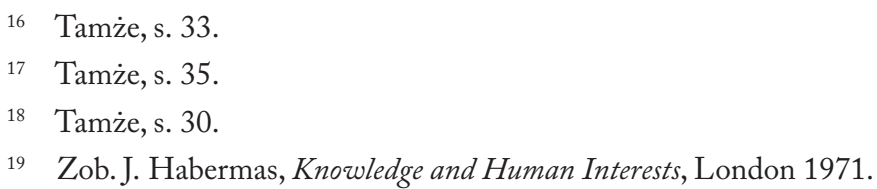


W koncepcji Davida Kolba ${ }^{20}$ refleksyjność uznana jest za aktywność umysłową, która jest niezbędna do uczenia się na podstawie doświadczenia. Autor jest twórcą empirycznego cyklu nauki, nazywanego także modelem uczenia się przez doświadczenie. W tym cyklu wyróżnione zostały cztery etapy: doświadczenie, refleksja, generalizacja, zastosowanie ${ }^{21}$. Osoba doświadcza czegoś, wykonuje to, czego chce się nauczyć, i nadaje temu przeżyciu strukturę. Następnie dokonuje refleksji (autorefleksji) nad tym doświadczeniem, wyciąga wnioski. Refleksyjność ma miejsce podczas aktywnej obserwacji i jest podstawą do czynnego eksperymentowania. $Z$ kolei na etapie generalizacji następuje skonfrontowanie sformułowanych wniosków z teorią, która leży u podstaw wyjaśnienia zaobserwowanego zjawiska. Następnie przechodzi na etap zastosowania, aktywnego eksperymentowania. Polega to na powiązaniu sformułowanej teorii z przyszłym praktycznym działaniem, na używaniu nowych wiadomości w sytuacjach praktycznych. To z kolei prowadzi do wytworzenia nowego doświadczenia, które jest źródłem nowej wiedzy.

Inną koncepcję refleksyjności przedstawił Donald Schön ${ }^{22}$, który opisał refleksję jako mechanizm budowania zawodowego i osobistego rozwoju. Do literatury pedagogicznej wprowadził pojęcie „refleksyjny praktyk" (ang. reflective practitioner). W Encyklopedii pedagogicznej $X X I$ wieku przedstawione jest ono jako osobne, szeroko omówione hasło, co podkreśla jego rangę i znaczenie w pedagogice. Według definicji, refleksyjny praktyk to „człowiek wykorzystujący refleksję (głęboki namysł) nad własnym, praktycznym doświadczeniem do osiągnięcia mistrzostwa w wykonywanym (nie tylko nauczycielskim) zawodzie"23. Termin ten zyskał popularność dzięki udowodnieniu, że jest możliwe połączenie doświadczenia zawodowego i krytycznego myślenia, któremu doświadczenie może i powinno być poddawane ${ }^{24}$.

20 Zob. D. Kolb, Experiential Learning: Experience as the Source of Learning and Development, Englewood Cliffs (NJ) 1984.

21 Por. I. Kazimierska, I. Lachowicz, L. Piotrowska, Uczenie się dorostych - cykl Kolba, Ośrodek Rozwoju Edukacji, Warszawa 2014, s. 3.

22 Zob. D. Schön, The Reflective Practitioner: How Professionals Think in Action, New York 1983.

23 W. Woronowicz, Refleksyjny praktyk, w: Encyklopedia pedagogiczna XXI wieku, dz. cyt., s. 72.

24 Por. Ch. Day, Rozwój zawodowy nauczyciela, tłum.J.Michalak, Gdańsk 2004, s. 51. 
Według koncepcji Donalda Schöna, zwanej także „epistemologią refleksyjnej praktyki” ${ }^{25}$, profesjonalista korzysta w sposób krytyczny z wiedzy teoretycznej. Potrafi ją zweryfikować, zgodnie z zaistniałymi sytuacjami, szczególnie trudnymi czy też nieprzewidywalnymi. Jest to działanie świadome teoretycznie, refleksyjne i modyfikujące. W pracy korzysta $\mathrm{z}$ wiedzy opartej na doświadczeniu. $Z$ kolei doświadczenie jest budowane na podstawie wykonywania konkretnych czynności. Dlatego też refleksyjny praktyk kształtuje swoje kompetencje odwołując się do własnego, praktycznego doświadczenia, ze świadomością, że mają one charakter dialogowy, wymagają ciągłego sprawdzania, problematyzowania i nadawania im nowego sensu. Punktem wyjścia tak rozumianej roli nauczyciela jest namysł nad związkiem między wiedzą teoretyczną a praktyczną jego działalnością.

Refleksyjny praktyk stosuje dwa rodzaje refleksji: w działaniu i po działaniu. Refleksję w działaniu D. Schön nazwał „pewnego rodzaju eksperymentowaniem"26, do którego dochodzi się w sytuacjach bieżących, różniących się od wcześniejszych, problemowych i niepewnych. Celem refleksji w działaniu jest zmiana zaistniałej sytuacji. Dlatego refleksyjny praktyk, próbując zrozumieć zaistniałą sytuację, wykonuje działanie, wprowadza zmianę, a przez to zwiększa się świadomość sytuacji. Jest to pewnego rodzaju „spirala refleksyjna", ciąg: rozumienie-działanie. Refleksja w działaniu występuje w czasie aktywności. $Z$ kolei refleksja po działaniu jest krytycznym spojrzeniem na kwestię działania po jego zakończeniu. D. Schön wyjaśnia również, że refleksyjni praktycy mają umiejętność postrzegania zaistniałej sytuacji, jakby mieli już z nią do czynienia, i działają w taki sposób, jak działali w podobnej sytuacji - nazywa to „widzieć-jak” i „działać-jak”27.

Omawiając to zagadnienie Henryka Kwiatkowska stwierdziła, że Donald Schön zwrócił uwagę, iż o sukcesie profesjonalnego działania jednostki decyduje samoświadomość działania. Dlatego też rola refleksji staje się kluczowa zarówno w uczeniu się czynności zawodowych, jak i w ich wykonywaniu, szczególnie w sytuacjach problemowych ${ }^{28}$.

25 Por. D. Schön, The Reflective Practitioner, dz. cyt., s. 131.

26 Tamże, s. 132.

27 Por. tamże, s. 140.

28 Por. H. Kwiatkowska, Pedeutologia, dz. cyt., s. 64. 
Należy również zauważyć, że umiejętność refleksji uznawana jest za istotny cel kształcenia nauczycieli. W standardach kształcenia przygotowujących do wykonywania zawodu nauczycieli stwierdza się, że absolwent posiada cechy refleksyjnego praktyka, ma świadomość poziomu swojej wiedzy i umiejętności, rozumie potrzebę ciągłego dokształcania się zawodowego i rozwoju osobistego, dokonuje oceny własnych kompetencji i doskonali umiejętności w trakcie realizowania działań pedagogicznych (dydaktycznych, wychowawczych i opiekuńczych) ${ }^{29}$. Profesjonalny nauczyciel to nie racjonalny technokrata, który stosuje teorię naukową w praktyce, ale refleksyjny praktyk, który poprzez namysł nad działaniem dochodzi do zrozumienia konkretnych sytuacji i modyfikowania zachowań ${ }^{30}$. Z kolei podstawą refleksyjnego działania jest zdolność dokonywania przemyślanych wyborów oraz umiejętność wyciągania wniosków z dotychczasowych działań. Efektem zaś jest zdobywanie i restrukturyzacja wiedzy - wiedzy praktycznej ${ }^{31}$. Można zatem stwierdzić, że refleksyjny praktyk nie musi być doskonały, wręcz przeciwnie, oczekuje się, że będzie wprowadzał teorię w działanie, będzie obserwował efekty tego działania, stawiał hipotezy, testował i wyciągał wnioski, i w ten sposób będzie uczył się oraz doskonalił swój warsztat, nie bojąc się nowości i zmian.

Należy zauważyć, że pomimo wielu różnic dotyczących pojmowania myślenia, myślenia refleksyjnego, uczenia się refleksyjnego oraz związków refleksyjności z działaniem, w przedstawionych koncepcjach ważna jest rola doświadczenia. Warto podkreślić, że już J. Dewey ${ }^{32}$ zwrócił uwagę na rolę doświadczenia i wiedzy w dokonywaniu refleksji. Są one punktami odniesienia, bez których namysł nad problemem może nie przynieść rozwiązania. Tylko doświadczenie zdobyte w analogicznych sytuacjach w życiu oraz wcześniej przyswojona wiedza mogą zagwarantować efektywną refleksję. Wartość doświadczenia i wiedzy wydaje się zatem niepodważalna. Doświadcze-

29 Por. Rozporządzenie Ministra Nauki i Szkolnictwa Wyższego z dnia 17 stycznia 2012 r. w sprawie standardów kształcenia przygotowującego do wykonywania zawodu nauczycieli, Dz.U. 2012, poz. 131.

30 Por. H. Kwiatkowska, Pedeutologia, dz. cyt., s. 68.

31 Por. J. Szymczak, Ze zdarzeniami krytycznymi w tle. Namyst nad refleksja w zawodzie nauczyciela, „Teraźniejszość - Człowiek - Edukacja” 2010, nr 4(52), s. 70.

32 Por. J. Dewey, Jak myślimy?, dz. cyt., s. 37. 
nie nabiera większej wartości dzięki refleksji. Istnieje wiele sposobów poddawania refleksji swojego doświadczenia. Niewątpliwie należy stwierdzić, że to właśnie refleksja i analiza mają wartość kształcącą i mogą być dobrym nauczycielem.

Podsumowując, w wymiarze poznawczym zwraca się uwagę na związek refleksyjności z formami myślenia, procesami uczenia się i profesjonalizacją. Natomiast w aspekcie pedagogicznym refleksyjność omawiana jest szczególnie w odniesieniu do procesów uczenia się. W takim ujęciu jest umiejętnością, której można się nauczyć i można ją rozwijać. Dlatego tak ważne jest odpowiednie organizowanie uczenia się uwzględniającego doświadczenie i aspekt praktyczny.

\section{Refleksyjność jako proces poznawania siebie}

W procesie wychowania, trwającym przez całe życie człowieka, refleksyjność jest bardzo istotna i konieczna. W tym aspekcie może być ona różnie rozumiana i ujmowana, dlatego też zostanie przedstawiona w perspektywie procesu poznawania samego siebie. Tak ujmowana refleksyjność stanowi dla teorii pedagogicznej oraz edukacji istotny punkt odniesienia, bowiem dotyczy kluczowego problemu podmiotu i zachodzącego $\mathrm{w}$ nim procesu stawania się.

Refleksyjność, ujmowana jako ogólna cecha człowieka, jest umiejętnością zastanawiania się nad samym sobą oraz nad kontekstem działania. Prowadzi do samoświadomości i podmiotowości. Zdaniem Roberta Kwaśnicy,

autorefleksja jest samorozumieniem wzbudzanym i podtrzymywanym wciąż przez to samo pytanie: jaki powinienem być i w jaki sposób powinienem postępować, by z jednej strony dochować wierności sobie i nie ulec duchowemu zniewoleniu, a $\mathrm{z}$ drugiej - by swoim postępowaniem nie ograniczać innych ludzi w ich prawach do wewnętrznej wolności i podmiotowości i w prawie do wyboru własnej drogi? ${ }^{33}$.

Według Charlotte Auli Davies, refleksyjność to „spoglądanie na samego siebie, to proces, w którym badacz odnosi się do siebie

33 Por. R. Kwaśnica, Wprowadzenie do myślenia o nauczycielu, w: Pedagogika. Podręcznik akademicki, t. 2, red. Z. Kwieciński, B. Śliwerski, Warszawa 2004, s. 300 . 
samego" ${ }^{34}$. Warto zaznaczyć, że refleksja prowadzi do dostrzeżenia i eliminacji własnych błędów, niepowodzeń, modyfikacji własnych działań, bowiem stały rozwój i doskonalenie zapewni tylko racjonalna autoanaliza i autoobserwacja, które są fundamentem autonomii człowieka. Należy zatem stwierdzić, że autorefleksyjność to praca, własny wysiłek rozumienia siebie, własnych postaw i działań, które należy stale analizować, oceniać i modyfikować. $Z$ autorefleksją ściśle związane są takie pojęcia jak: samoocena, samoobserwacja, samowiedza czy samopoznanie.

Refleksyjność jest bardzo ważna w konstruowaniu samoświadomości człowieka. Przyczynia się do budowy „warstwy przeżyć człowieka”35 , która staje się bazą do poznawania i rozumienia świata. Refleksja towarzysząca pozwala sukcesywnie odsłonić swoje wnętrze. Człowiek przekonuje się o własnej indywidualności osobowej, racjonalności, a także o własnej niepowtarzalności i wolności. Jest to doświadczenie „o charakterze przeżywaniowym (samoodsłaniającym się) i towarzyszącym" ${ }^{36} \mathrm{w}$ trakcie własnego działania.

Refleksja nieaktowa (towarzysząca lub przeżywaniowa) odgrywa szczególną rolę w wymiarze jedności osoby ludzkiej, ponieważ „stanowi ważny współczynnik doświadczenia przez człowieka «na bieżąco» siebie jako całościowej integralnej jedności w toku jego życia osobowego" ${ }^{37}$. Refleksja ta prowadzi do odsłonięcia ważnych sfer życia: intelektualnej, poznawczej, moralnej, interpersonalnej i duchowej. Dzięki temu człowiek, z zasady subiektywny, dokonuje refleksji nad własnymi sądami i opiniami, wprowadzając do życia element wartości obiektywnej, który z kolei jest niezbędnym warunkiem funkcjonowania człowieka jako osoby ${ }^{38}$. Refleksja, szczególnie przeżywaniowa, jest „wewnętrznym sądem praktycznym, stanowi ostateczne kryterium ludzkiego czynu - sumienie" ${ }^{\prime 39}$.

34 Ch.A. Davies, Reflexive Ethnography: A Guide to Researching Selves and Others, London 2002, s. 4.

35 W. Chudy, Refleksja, w: Encyklopedia pedagogiczna XXI wieku, dz. cyt., s. 69.

36 Tamże.

37 Tamże.

38 Por. tamże, s. 69.

39 Tamże. 
Wojciech Chudy wyjaśnia, że człowiek dokonujący refleksji nad samym sobą i światem staje w obliczu dwóch horyzontów refleksyjnych: horyzontu ,ja" i horyzontu bytu ${ }^{40}$. Horyzont ,ja" wskazuje na „myślenie w głąb świadomości”"11 o własnym istnieniu, miedzy innymi o tym, kim jestem, co posiadam, o moich wartościach, wiedzy i odpowiedzialności. Należy zauważyć, że „spiętrzenie się w nieskończoność aktów refleksji nad sobą grozi niebezpieczeństwem”², bowiem człowiek może popaść w pułapkę refleksyjną, dlatego ważne jest zrównoważenie horyzontu ,ja" z horyzontem bytu, który wskazuje na istnienie rzeczywistości obiektywnej, świata realnego. Jest to niezmiernie ważne, gdyż - zdaniem Wojciecha Chudego - „nie uzyskamy kontaktu ze sobą, o ile nie będziemy mieli kontaktu z rzeczywistością; poznając byt, poznajemy siebie" ${ }^{43}$. Bez refleksji człowiek poznawałby świat w sposób jedynie subiektywny, czyli niepełnie.

Reasumując, należy zauważyć, że refleksyjność jest także umysłową zdolnością do zastanawiania się nad sobą w odniesieniu do własnego, dostępnego kontekstu społecznego. Poznawanie siebie, praca nad sobą, to wielkie zadanie, jakie staje przed każdym człowiekiem. Dlatego nadal wciąż aktualne są słowa wypowiedziane przez Jana Pawła II: „Musicie od siebie wymagać, nawet gdyby inni od Was nie wymagali" ${ }^{\prime}$.

\section{Podsumowanie}

W procesie wychowania, który zmierza za pomocą właściwych metod i środków do określonych i celowych zmian w osobowości człowie$\mathrm{ka}$, a te z kolei przyczyniają się do jego wszechstronnego i pożądanego rozwoju, refleksyjność jest bardzo ważna i konieczna. Refleksyjność zaczyna się wówczas, kiedy człowiek głęboko zastanawia się nad sobą, nad tym, co robi, oraz rozważa wiedzę, którą posiada, po to, by ją rozpoznać i ulepszyć. Szczególnie w praktyce pedagogicznej są sytuacje, które

$40 \quad$ Por. tamże, s. 70.

41 Tamże.

42 Tamże.

43 Tamże, cyt. za M.A. Krąpiec, Cztowiek - suwerenny byt osobowy - w ujęciu Karola Wojtyty, „Zeszyty Naukowe KUL” 1979, nr 1-13, s. 65-71.

44 Jan Paweł II, Apel Jasnogórski. Rozważanie wygtoszone do mtodzieży, Częstochowa, 18 czerwca 1983, <http://nauczaniejp2.p1/dokumenty/wyswietl/ id/633> [dostęp: 4.10.2016]. 
wymagają zmiany strategii działania. Dlatego też w pracy wychowawcy, naznaczonej unikatowością i niestabilnością sytuacji wychowawczych, refleksyjność staje się sposobem rozwiązywania problemów i radzenia sobie w różnorodnych okolicznościach. Można stwierdzić, że to właśnie myślenie refleksyjne ma wartość kształcącą. Moment refleksji stanowi ważne wyzwanie zarówno dla wychowawcy,jak również dla wychowanka. W procesie wychowania ważne jest, „aby nie przeszkadzać dziecku, uczniowi, wychowankowi, ale by mu asystować, wspomagać" ${ }^{45}$. W tym procesie kształtuje się również osobista refleksja wychowawcy oraz wychowanka. To „potwierdza tezę o potrzebie wychowania innych do refleksji i stałej dbałości o jakość refleksji w sobie samym" ${ }^{\prime 4}$.

Niewątpliwie od wychowawcy należy oczekiwać postawy otwartości, odwagi i refleksyjności. Dlatego ważne jest, by refleksja była dla każdego $z$ nas procesem formacyjnym rodzącym potrzebę wyjścia poza sferę poznania i motywującym do działania. Warto zatem zarówno w teorii, jak również w praktyce pedagogicznej podejmować dalsze i szersze badania odnoszące się do problematyki refleksyjności $\mathrm{w}$ procesie wychowania.

\section{Bibliografia}

Chudy W., Refleksja, w: Encyklopedia pedagogiczna XXI wieku, t. 5, red. T. Pilch, Wydawnictwo Akademickie „Żak”, Warszawa 2006, s. 68-72.

Davies Ch.A., Reflexive Ethnography: A Guide to Researching Selves and Others, Routledge, London 2002.

Day Ch., Rozwój zawodowy nauczyciela, tłum. J. Michalak, Gdańskie Wydawnictwo Psychologiczne, Gdańsk 2004.

Dewey J., Jak myślimy?, tłum. Z. Bastgenówna, PWN, Warszawa 1988.

Habermas J., Knowledge and Human Interests, Heinemann, London 1971.

Hałas E., Refleksyjnoś jako zasada i problem teorii spotecznej, „Zagadnienia Naukoznawstwa" 2011, nr 2(188), s. 191-202.

Hejnicka-Bezwińska T., Pedagogika ogólna, Wydawnictwa Akademickie i Profesjonalne, Warszawa 2008.

Jan Paweł II, Apel Jasnogórski. Rozważanie wygtoszone do mtodzieży, Częstochowa, 18 czerwca 1983, <http://nauczaniejp2.p1/dokumenty/wyswietl/ id/633> [dostęp: 4.10.2016].

45 K. Zdziarski, Nauczyciel - refleksyjny praktyk - puzzle pedagogiczne, w: Innowacyjnośc w zarzadzaniu edukacja, red. L. Pawelski, Szczecinek 2015, s. 315.

46 Tamże, s. 313. 
Kazimierska I., Lachowicz I., Piotrowska L., Uczenie się dorostych - cykl Kol$b a$, Ośrodek Rozwoju Edukacji, Warszawa 2014.

Kolb D., Experiential Learning: Experience as the Source of Learning and Development, Prentice-Hall, Englewood Cliffs (NJ) 1984.

Kopaliński W., Stownik wyrazów obcych i zwrotów obcojezycznych, Wiedza Powszechna, Warszawa 1989.

Krąpiec M.A., Cztowiek - suwerenny byt osobowy - w ujeciu Karola Wojtyty, „Zeszyty Naukowe KUL”1979, nr 1-13, s. 65-71.

Kwaśnica R., Wprowadzenie do myślenia o nauczycielu, w: Pedagogika. Podręcznik akademicki, t. 2, red. Z. Kwieciński, B. Śliwerski, Wydawnictwo Naukowe PWN, Warszawa 2004, s. 291-320.

Kwiatkowska H., Pedeutologia, Wydawnictwa Akademickie i Profesjonalne, Warszawa 2008.

Langer E., Problemy uświadamiania. Konsekwencje refleksyjności i bezrefleksyjności, w: Poznanie. Afekt. Zachowanie, red. T. Maruszewski, Wydawnictwo Naukowe PWN, Warszawa 1993, s. 137-179.

Refleksyjnośc, w: Stownik jezyka polskiego, red. M. Szymczak, PWN, Warszawa 1981.

Rozporząadzenie Ministra Nauki i Szkolnictwa Wyższego z dnia 17 stycznia 2012 r. w sprawie standardów kształcenia przygotowującego do wykonywania zawodu nauczycieli, Dz.U. 2012, poz. 131.

Schön D., The Reflective Practitioner: How Professionals Think in Action, Basic Books, New York 1983.

Szymczak J., Ze zdarzeniami krytycznymi w tle. Namyst nad refleksja w zawodzie nauczyciela, „Teraźniejszość - Człowiek - Edukacja” 2010, nr 4(52), s. 55-74.

Tchorzewski A.M. de, Wstęp do teorii wychowania, Akademia Ignatianum w Krakowie - Wydawnictwo WAM, Kraków 2016.

Woronowicz W., Dydaktyka wobec wptyrwu spotecznego, w: Edukacja jutra. VI Tatrzañskie Seminarium Naukowe, red. K. Denek, T.M. Zimny, Agencja Promocji Nauki i Kultury „Menos”, Częstochowa 2000, s. 73-83.

Woronowicz W., Refleksyjny praktyk, w: Encyklopedia pedagogiczna XXI wieku, t. 5, red. T. Pilch, Wydawnictwo Akademickie „Żak”, Warszawa 2006, s. 72-74.

Zdziarski K., Nauczyciel - refleksyjny praktyk - puzzle pedagogiczne, w: Innowacyjnośc w zarzadzaniu edukacja, red. L. Pawelski, Polskie Stowarzyszenie Nauczycieli Twórczych, Szczecinek 2015, s. 311-316.

\section{ADRES DO KORESPONDENCJI:}

Dr Marzena Chrost

Akademia Ignatianum w Krakowie

Wydział Pedagogiczny

Instytut Nauk o Wychowaniu

marzena.chrost@ignatianum.edu.pl 